\title{
Isolation and Speciation of Candida from Various Clinical Samples in a Tertiary Care Hospital
}

\author{
Nirmaladevi Somsundaram* \\ Department of Microbiology, Government Mohan kumaramangalam Medial College, \\ Salem, Tamil Nadu, India \\ *Corresponding author
}

\section{A B S T R A C T}

Keywords

Candida, Hichrom agar,

Germ tube test,

Morphology, Speciation,

Antifungal susceptibility

Article Info

Accepted:

10 April 2018

Available Online:

10 May 2018
Infections due to Candida species and other fungi have increased dramatically in recent years. Candida isolates from various clinical samples were collected and inoculated on SDA. Speciation was done by Germ tube test, Hichrom agar, and morphology on corn meal with Tween 80.64 were culture positive. Of this, 47(73\%) C. albicans and $17(27 \%)$ non albicans Candida were isolated. Hichrom agar can be used for rapid, presumptive identification of Candida species.

\section{Introduction}

Infections due to candida species and other fungi have increased dramatically in recent years. (Fraser et al., 1992) Candida is a yeast like fungi belongs to the sub class of Ascomycota. The genus is composed of a heterogeneous group of organisms, and nearly 20 of these species are considered to be significant pathogens of which 7 of them are well known pathogens to cause opportunistic infections.

Although $C$. albicans remains the most common cause of human candidiasis, now for the past four decades non-albicans candida species like $C$. glabrata, $C$. krusei, $C$. parapsilosis, C. tropicalis and C. rugosa, are emerging as important opportunistic pathogen which have shown increased resistance to antifungal agents (Abi-said et al., 1997). These candida species differ in their expression of putative virulence factors and antifungal Susceptibility (Baillie and Douglas, 1998). This necessitates the rapid species level identification of Candida as an essential task for the clinical mycology laboratory since it has a direct bearing on treatment decisions

\section{Materials and Methods}

About 64 Candida isolates from various clinical samples (Urine, Blood, High vaginal swab, Pus, Sputum) are taken up for the study 
for a period of 3 months. A detailed clinical history was taken with regards to the age, sex, underlying disease/ conditions, Immunodeficiencies like Dibetes mellitus, Human Immunodeficiencies virus infection etc....., As per the standard operating Procedures all the clinical specimens were inoculated on blood agar and Mac Conkey agar Except blood samples which were inoculated in biphasic brain heart infusion broth. The culture plates are incubated aerobically at $37^{\prime} \mathrm{c}$ for 24 to 48 hours. The visual growth is Stained and the one which revealed gram positive budding yeast cells with or without pseudohyphae are confirmed as Candida. All the isolated Candida colonies are inoculated immediately on Sabourauds Dextrose Agar (SDA) and incubated at $37^{\circ} \mathrm{C}$ for 24- $48 \mathrm{hrs}$.

Raynaulds Braude phenomenon was observed by inoculating the colonies in $0.5 \mathrm{ml}$ of human serum and incubating at $37^{\circ} \mathrm{C}$ for $1-2 \mathrm{hrs}$. (Forbes et al., 2007)

Inoculation on Hichrome agar media and incubated at $37^{\circ} \mathrm{C}$ for $24-48 \mathrm{hrs}$. The characteristic colour and morphology of the colonies were noted as per the manufacturer's instruction. (Hichromagar; $\mathrm{Hi}$ Media, Mumbai, India) (Baradkar et al., 2010)

Formation of chlamydospores was identified by Dalmau plate culture method in Corn meal agar with $1 \%$ tween-80 incubated for 2- 3 days at room temperature. (Ann P. Koehler et al., 1999) Observed for the presence of true hyphae or pseudohyphae, blastoconidia, arthroconidia and Chlamydospores

\section{Results and Discussion}

About 64 isolates were culture positive for Candida species on SDA plate. 27 urine samples, 17 high vaginal swabs, 13 pus samples, 4 sputum and 3 blood samples had shown a growth of candida species (Table 1). Of this $23(36 \%)$ were males and $41(64 \%)$ were females (Table 2). Among the 64 isolates, Germ tube test was positive in 47 (73\%) isolates and were identified as $C$. albicans (Table 3).

Out of the 64 isolates, $47(73 \%)$ isolates were produced apple green colonies (C. albicans), $7(11 \%)$ pink colonies (C. krusei), 4(6\%) white to pale pink colonies (C. tropicalis), $3(5 \%)$ blue colonies (C. parapsilosis), and $3(5 \%)$ purple colonies ( $C$. glabrata) on Hichrom agar (Table 4).

On Corn meal agar with Tween-80, chlamydospores were demonstrated in all 47 (73\%) C. albicans isolates.

Fungal infection especially by Candida species, are becoming increasingly common. So their optimum identification and isolation will help the clinicians to know the pathogen and their susceptibility pattern. This will guide them to institute proper drugs thereby avoiding any treatment failures. Further the high level resistance to azoles among non albicans Candida isolates emphasizes the need for species directed treatment.

About 64 isolates were culture positive for Candida species on SDA plate. 27 urine samples, 17 high vaginal swabs, 13 pus samples, 4 sputum and 3 blood samples has shown a growth of candida species. Of this 23 $(36 \%)$ were males and $41(64 \%)$ were females. Among the 64 isolates, Germ tube test was positive in $47(73 \%)$ isolates and were identified as $C$. albicans.

Growth was observed in $23(36 \%)$ males and $41(64 \%)$ females indicating that women are at increased risk to develop UTI than men. (Koneman et al., 2006) Of the 64 Candida isolates, 47 (73\%) were Candida albicans and 17 (27\%) were non-albicans Candida. 
Table.1 Culture positivity of Candida species from various clinical samples

\begin{tabular}{|l|l|c|c|}
\hline S. No & Nature of sample & $\begin{array}{r}\text { No of samples shown growth } \\
\text { on SDA }\end{array}$ & Percentage (\%) \\
\hline 1. & Urine & 27 & 54 \\
\hline 2. & High vaginal swab & 17 & 17 \\
\hline 3. & Pus & 13 & 15 \\
\hline 4. & Sputum & 4 & 8 \\
\hline 5. & Blood & 3 & 6 \\
\hline & Total & 64 & 100 \\
\hline
\end{tabular}

Table.2 Gender distribution of Candida species from various clinical samples

\begin{tabular}{|c|c|c|}
\hline Gender & No of patients & Percentage (\%) \\
\hline Male & 23 & $36 \%$ \\
\hline Female & 41 & $64 \%$ \\
\hline Total & 64 & $100 \%$ \\
\hline
\end{tabular}

Table.3 Distribution of Candida albicans and Non albicans isolates ( $\mathrm{n}=64)$ based on Germ Tube Test

\begin{tabular}{|c|c|c|}
\hline Germ Tube Test & No. (\%) of isolates & Candida Species \\
\hline Positive & $47(73 \%)$ & C. albicans \\
\hline Negative & $17(27 \%)$ & Non-albicans Candida \\
\hline Total & $64(100 \%)$ & \\
\hline
\end{tabular}

Table.4 Species distribution of the Candida isolates $(\mathrm{n}=64)$ by HiChrom agar

\begin{tabular}{|c|c|}
\hline Species & Number of Candida isolates \\
\hline C. albicans & $47(73 \%)$ \\
\hline C. krusei & $7(11 \%)$ \\
\hline C. tropicalis & $4(6 \%)$ \\
\hline C. parapsilosis & $3(5 \%)$ \\
\hline C.glabrata & $3(5 \%)$ \\
\hline
\end{tabular}

Among the 17 non-albicans Candida species, C. krusei $7(11 \%)$ C. tropicalis $4(6 \%), C$ parapsilosis $3(5 \%)$, and C. glabrata $3(5 \%)$ were isolated. In our study C. krusei 7 (11\%) was the most common non albicans species isolated. Whereas (Latiff et al., 2004) reported that $C$. parapsilosis was the most common non albicans species accounting for $21 \%$ and $8 \%$ respectively. Whereas (Shivprakash et al., 2007) (36\%) and (Enwuru et al., 2008) (18\%) documented $C$. tropicalis was the most common non albicans species. In this present study $C$. dubliensis was not isolated.

As PCR is expensive and not available at all places, it was observed in the present study that species identification of Candida can be done by using Hichrome agar (Mokaddas et al., 2007) and the isolates were further confirmed by sugar assimilation and other biochemical tests. This indicates that Hichrome agar can be used at field level for rapid presumptive 
identification. This medium also carries the potential of improving identification of Candida from mixed cultures

This study implies that Hichrom agar can be used for rapid, presumptive identification of Candida species, which improves the identification of mixed candidial infection. Since intrinsic resistance was observed in non albicans Candida species, speciation is in need of the day. Knowledge of the susceptibility pattern will prevent the resistance of available few antifungal agents.

\section{References}

Abi-said D, Anaissie E, Uzun O, Raad I, Pinzcowski H, Vartivarian S. The epidemiology of hematogenous candidiasis caused by different Candida species. Clin infect Dis 1997; 24:1112-28.

Ann P. Koehler, Kai-Cheong Chu, Elizabeth TS. Houang, and Augustine FB Cheng. Simple, Reliable, and cost-effective yeast identification scheme for the clinical laboratory. J Clin Microbiol 1999; 37: 422-26.

Baillie GS, and Douglas LJ. Iron limited biofilms of Candida albicans and their susceptibility to Amphotericin B. Antimicrob Agents Chemother 1998; 42:2146-49.

Baradkar VP, Mathur M, Kumar S. Hichrom Candida agar for identification of Candida species. Indian $\mathrm{J}$ Pathol Microbiol 2010; 53:93-95.

Enwuru, C.A., A Ogunledun, $\mathrm{N}$ Idika, NV Enwuru, F Ogbonna, M Aniedobe, et al., Fluconazole resistant opportunistic oro- pharyngeal candida and non-candida yeast-like isolates from HIV infected patients attending ARV clinics in Lagos, Nigeria. Afr Health Sci 2008; 8(3): 14248.

Forbes BA, Sahm DF, Weissfeld AS. Bailey and Scott's Diagnostic Microbiology.12th edition. Part V, Laboratory Methods in Basic Mycology. St. Louis: Mosby; 2007. p 629-716.

Fraser VJ, Jones M, Dunkel J, Storfer S, Medoff G, Dunagan WC. Candidemia in a tertiary care hospital: epidemiology, risk factors, and predictors of mortality. $\mathrm{J}$ Clin Infect Dis 1992; 15: 414-21.

Koneman E, Allen S, Janda W, Procop G, Schreckenberger $\mathrm{P}$, woods G. Colour Atlas and Textbook of diagnostic Microbiology. $6^{\text {th }}$ edition. Introduction to Microbiology. Philadelphia: Lippincott Williams \& Wilkins; 2006. p - 83.

Lattif AA, Banerjee U, Prasad R, Biswas A, Wig N, Sharma N, et al., Susceptibility pattern and molecular type of speciesspecific Candida in oropharyngeal lesions of Indian Human Immunodeficiency Virus-positive patients. J. Clin. Microbiol 2004; 42(3): 1260-62.

Mokaddas EM, Al-Sweih NA, Khan ZU. Species distribution and antifungal susceptibility of Candida bloodstream isolates in Kuwait:a 10-year study Indian J Med Microbiol 2007; 56: 255-59.

Shivaprakasha S, Radhakrishnan K, Karim PM. Candida spp. other than Candida albicans: a major cause of fungaemia in a tertiary care centre. Indian J Med Microbiol 2007; 25(4): 405-07.

\section{How to cite this article:}

Nirmaladevi Somsundaram. 2018. Isolation and Speciation of Candida from Various Clinical Samples in a Tertiary Care Hospital. Int.J.Curr.Microbiol.App.Sci. 7(05): 1143-1146. doi: https://doi.org/10.20546/ijcmas.2018.705.139 